\title{
Clinical Guidelines and Implementation into Daily Dental Practice
}

\section{Normas Clínicas e sua Implementação na Prática Médico Dentária}

\section{Guliz Nigar GUNCU $\triangle^{1}$, Secil Karakoca NEMLI², Eunice CARRILHO ${ }^{3}$, Nermin YAMALIK ${ }^{4}$, Elena VOLODINA ${ }^{5}$,} Paulo MELO 6,7 , Vladimer MARGVELASHVILI ${ }^{8}$, Alessandra ROSSI ${ }^{9}$

Acta Med Port 2018 Jan;31(1):12-21 - https://doi.org/10.20344/amp.8942

\section{ABSTRACT}

Introduction: The purpose of this study is to assess the extent of the familiarity, attitude and perceptions of dental professionals regarding clinical dental guidelines and their implementation into daily dental practice.

Material and Methods: For this purpose, a questionnaire which was developed by the members of the World Dental Federation, European Regional Organization Working Group - 'Relation Between Dental Practitioner and Universities', was implemented by the National Dental Associations of six European Regional Organization-zone countries (Georgian Stomatological Association - Georgia, Associazione Nazionale Dentisti Italiani - Italy, Portuguese Dental Association - Portugal, Russian Dental Association - Russia, Swiss Dental Association - Switzerland, and Turkish Dental Association - Turkey. The questionnaire was filled by a total of 910 dental professionals who are members of one of these national dental associations and who voluntarily wanted to participate to this survey. Results: Most of the survey participants were familiar with clinical dental guidelines (68\%), claimed that they implemented them into daily practice $(61.7 \%)$, and generally acknowledged their benefits $(81.8 \%)$. Many participants believed that clinical dental guidelines could help to improve the clinical treatment plan $(50.6 \%)$ and the accuracy of diagnosis $(39.4 \%)$; which increased with age and years of practice $(p<0.05)$. The most frequently perceived barrier to the effective implementation of clinical dental guidelines was expressed as 'lack of awareness', while participants suggested a role for national dental associations in spreading clinical dental guidelines.

Discussion: A better understanding of the perceptions and attitudes of dentists towards clinical dental guidelines and the potential impact of factors affecting such perceptions and attitudes may be of particular importance for attempts aiming at overcoming the barriers for effective implementation of clinical dental guidelines into daily practice.

Conclusion: Despite a significant familiarity and a common positive attitude, dental professionals are likely to have different perceptions towards clinical dental guidelines, especially regarding their effective implementation into daily practice, benefits and barriers.

Keywords: Evidence-Based Dentistry; Practice Patterns, Dentists; Surveys and Questionnaires

\section{RESUMO}

Introdução: Este estudo tem como objetivo avaliar a abrangência da familiaridade, das atitudes e das perceções dos profissionais da área da saúde oral em relação às normas clínicas dentárias e a sua implementação na prática da Medicina Dentária diária.

Material e Métodos: Com esta finalidade, desenvolveu-se um questionário pelos membros da Federação Dentária Mundial, pelo Grupo de Trabalho da Organização Regional Europeia - "Relação entre Médicos Dentistas e as Universidades" e, foi implementado pelas Associações de Medicina Dentária/Estomatologia Nacionais de seis países da Organização Regional Europeia (Associação Estomatológica da Geórgia - Geórgia, Associação Nazionale Dentisti Italiani - Itália, Ordem dos Médicos Dentistas - , Associação Dentária Russa - Rússia, Associação Dentária Suiça - Suiça e Associação Dentária Turca - Turquia. O questionário foi preenchido por um total de 910 profissionais da área da saúde oral, membros de uma dessas associações de medicina dentária/estomatologia Nacionais e que, voluntariamente quiseram participar neste inquérito.

Resultados: A maioria dos entrevistados estava familiarizada com os normas clínicas dentárias (68\%) e implementam-nas na clínica diária $(61,7 \%)$ reconhecendo os seus benefícios $(81,8 \%)$. Muitos participantes acreditavam que as normas clínicas dentárias poderiam ajudar a melhorar o plano de tratamento clínico $(50,6 \%)$ e a precisão do diagnóstico $(39,4 \%)$; que aumentou com a idade e os anos de prática $(p<0,05)$. A barreira mais frequentemente percecionada para a implementação efetiva dos normas clínicas dentárias foi expressa como 'falta de conscientização'. Os participantes sugeriram o papel das associações de medicina dentária/estomatologia nacionais na disseminação das normas clínicas dentárias.

Discussão: Uma melhor compreensão das atitudes e perceções dos médicos dentistas em relação às normas clínicas dentárias, e do impacto potencial dos fatores que afetam tais atitudes e perceções, pode ser particularmente importante tendo em vista a necessidade de superar as barreiras existentes quando da implementação efetiva das normas clínicas dentárias na clínica diária.

Conclusão: Apesar da familiaridade significativa e de uma atitude positiva comum, os profissionais de saúde oral têm perceções diferentes em relação às normas clínicas dentárias, especialmente em relação à sua implementação efetiva na prática diária, benefícios e barreiras.

Palavras-chave: Inquéritos e Questionários; Odontologia Baseada em Evidências; Padrões de Prática de Dentistas

\footnotetext{
1. Department of Periodontology. Faculty of Dentistry. University of Hacettepe. Ankara. Turkey.

2. Department of Prosthodontics. Faculty of Dentistry. University of Gazi. Ankara. Turkey.

3. Operative Dentistry. Faculty of Medicine and Instituto Biomédico de Investigação da Luz e da Imagem. Universidade de Coimbra. Coimbra. Portugal.

4. Department of Periodontology. Faculty of Dentistry. University of Hacettepe. Ankara. Turkey.

5. Department of Cariology and Endodontia. Moscow State University of Medicine and Dentistry. Moscow. Russia.

6. Restorative Dentistry. Faculdade de Medicina Dentária. Universidade do Porto. Porto. Portugal.

7. Department of Oral Public Health. Instituto de Saúde Pública. Universidade do Porto. Porto. Portugal.

8. Department of Dentistry and Maxillofacial Surgery. Faculty of Medıcıne. Tbilisi State University. Tbilisi. Georgia.

9. Centro Specialistico Odontoiatrico Corso Italia 92. Roma. Italy.

$\triangle$ Autor correspondente: Guliz Nigar Guncu. guliz@hacettepe.edu.tr

Recebido: 12 de março de 2017 - Aceite: 11 de agosto de 2017 | Copyright @ Ordem dos Médicos 2018
} 


\section{INTRODUCTION}

A clinical decision-making is a routine for every health professional. Generally, by using their educational background, training, available data, scientific evidence and clinical expertise, they are able to make appropriate and optimal clinical decisions. However, this does not mean that additional scientific support is never needed. Clinical recommendations, position papers, consensus statements, position statements and clinical guidelines (CGs) essentially aim at providing such support for health professionals.

The Institute of Medicine (IOM) has described clinical practice guidelines as "systematically developed statements to assist practitioner and patient decisions about appropriate health care for specific clinical circumstances". ${ }^{1-3}$ More than two decades later, this definition was reviewed, highlighting the rigorous methodology in the processes of developing guidelines: "Clinical guidelines are statements that include recommendations intended to optimize patient care that are informed by a systematic review of evidence and an assessment of the benefits and harms of alternative care options", ${ }^{3}$ thus implying a dynamic relation between structure, process, and outcome. ${ }^{4}$ CGs has been widely accepted as a support and an essential part of quality practice for many decades. ${ }^{1}$ High-quality, evidence-based clinical practice guidelines offer a mode of bridging the gap between policy, best practice, local contexts and patient options, ${ }^{1,2}$ support effective clinical practice and bring potential benefits to practitioners and patients. ${ }^{5,6}$ They get research into practice by providing the link, reducing the gap between evidencebased literature and clinical practice, and providing users with consistent advice and common points of reference for assessing their performance against measurable criteria. ${ }^{6,7}$

While CGs are mainly developed to support and assist clinicians and patients, they can also help to improve and monitor patient safety, clinical effectiveness, and quality of care. ${ }^{8}$ Improved quality of care, efficiency and cost containment, ${ }^{9}$ reduced morbidity and mortality, ${ }^{10}$ increased patient knowledge and awareness on treatment about benefits and harm of various treatments, ${ }^{5,7}$ are all listed as goals and benefits. Recently, guidelines are being used in a more expanded manner in order to direct care delivered by individuals with less training and who are less well equipped to make judgment decisions, and the third party players and various government agencies which need strong and precise language to guide them in their application of the guidelines. ${ }^{11}$

Despite all these facts, development of CGs and their use in health care (including dentistry, nursing, medicine) is a process where certain questions and concerns also arise; including CG's reliability, validity, availability, dissemination and their efficacy and implementation into practice. Usually guidelines are developed by experts through consensus-based decision making. ${ }^{6,12}$ They are typically presented as a checklist with completion of key items required to adequately inform end users including clinicians, researchers, and guideline and policy developers. ${ }^{13,14}$ These 'recommendations' as some authors refer, are a useful tool to follow in most instances, but are not the absolute truth. ${ }^{15}$ Naturally, they should be based on the best available evidence ${ }^{15-17}$ and are meant to help healthcare professionals and patients in making the best decisions, without replacing the knowledge, experience and skills of individual practitioners. ${ }^{15}$ Although more guidelines may become available, they may still not be available in all fields of practice which may leave some of the clinical questions of health practitioners unanswered, while effective dissemination may not also always be achieved. ${ }^{7}$

On the other hand, availability of guidelines does not automatically ensure their use, due to the various barriers (e.g. lack of interest, lack of agreement, lack of involvement, lack of outcome expectancy, lack of time and lack of remuneration, fear of restricted professional autonomy, etc. ${ }^{8,18,19}$ ) for adapting guideline recommendations to clinical practice successfully. ${ }^{20}$ Further, little is known about the degree to which dental schools are teaching evidencebased guidelines or implementing them in their clinics. ${ }^{21}$

CGs, for the prevention and treatment of oral conditions, have been published, and some have already endorsed by dental specialty organizations. ${ }^{6}$ It should be added that some dental associations in Europe and North America have developed a quality assurance program, wherein the construction of nationwide clinical practice guidelines and inter-professional collaboration in dental peer groups, both on a voluntary basis, are essential parts. ${ }^{8,21}$ However, in many countries these guidelines do not seem to be systematically disseminated and implemented nationwide. ${ }^{8}$

As can easily be seen, the various debated issues in all health professions concerning CGs and their routine use, need further attention.

Thus, the purpose of the present study was to evaluate the extent of familiarity of dental professionals with clinical dental guidelines (CDGs), with a specific emphasis on their perceptions regarding the benefits of CDGs, the need for further improvement of the process of their development/ dissemination, and the potential barriers to their effective implementation into daily practice.

\section{MATERIAL AND METHODS}

A questionnaire by the FDI-ERO Working Group 'Relation Between Dental Practitioner and Universities' was developed. The questionnaire started with a specific section at the beginning where the background and the aims of the survey were briefly explained to the participants. There also was a section for demographic data (e.g. age, gender, years of practice, mode of practice, etc.), which was followed by a total of 16 questions. Questions essentially focused on the perceptions of dental professionals regarding the reliability of the available CDGs, the source of their knowledge on CDGs, their perceived barriers to effective implementation of CDGs into practice, their opinion regarding the organizational body to develop CDGs, the frequency of review for any existing CDGs, and their suggestions for a better and effective use of CDGs in daily practice [Appendix 1 (Full 
version of the Questionnaire developed by the European Regional Organization Working Group of the World Dental Federation - 'Relation Between Dental Practitioner and Universities'): https://www.actamedicaportuguesa. com/revista/index.php/amp/article/view/8942/5306]. The questionnaire also focused on the perceptions of dental professionals regarding the benefits of CDGs and they were asked to comment if CDGs particularly benefited dentists themselves, or their patients or the dental profession itself. The CDGs, which were subject to the questionnaire, were the valid CDGs in each country in the year (2015) when the survey was undertaken.

A total of six national dental associations (NDAs) in the World Dental Federation European Regional Organization Working Group FDI-ERO zone [Georgian Stomatological Association (GSA) Georgia, Associazione Nazionale Dentisti Italiani (ANDI) Italy, Portuguese Dental Association (PDA) Portugal, Russian Dental Association (RDA) Russia, Swiss Dental Association (SSO) Switzerland, and Turkish Dental Association (TDA) (Turkey)], voluntarily participated in the survey and these NDAs themselves conducted the survey among their members. While some NDAs preferred to conduct the survey by post (GSA, SSO), or by email (ANDI, RDA), others preferred to conduct an electronic survey through their official web sites (PDA, TDA). The survey was conducted between the months of May and June 2015.

The surveys in each country was conducted by the

Percentages of respondents from each countries

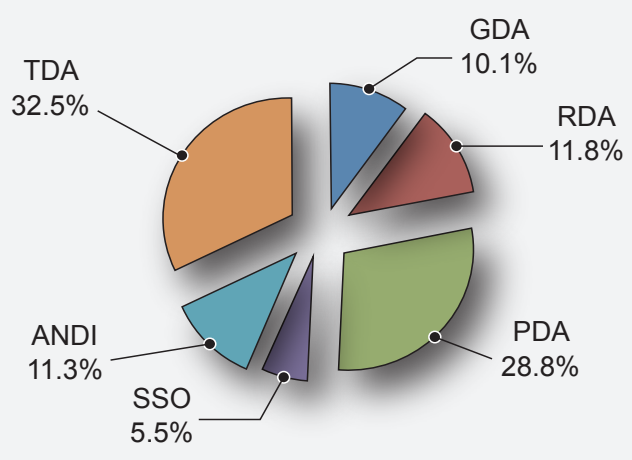

Who benefits from clinical guidelines and its implementation to dental practice?

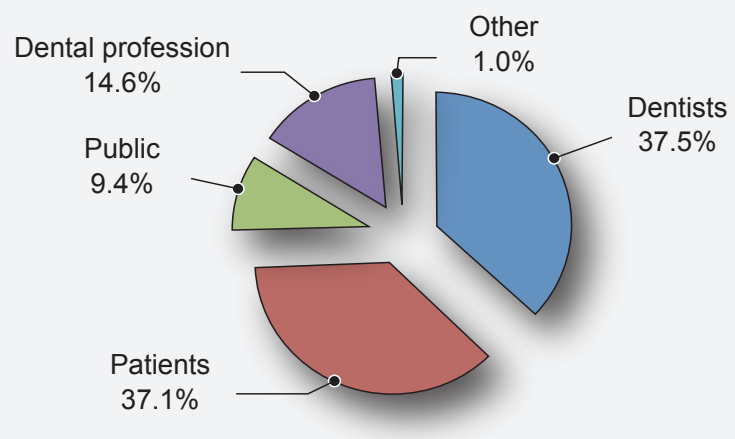

relevant NDA in the country. Members of NDAs participated in the survey on a voluntary basis. While some NDAs preferred to contact their members by e-mails or post (E.g. SSO, GSA), some preferred an on-line survey by giving link from their home page (E.g. PDA,TDA). The survey was translated into the local language in all countries, except SSO, where the survey was conducted in English. The present survey has been conducted in full accordance with the World Medical Association Declaration of Helsinki. ${ }^{22}$ Participants were all members of NDAs in their countries and were contacted only once by the relevant NDAs. NonNDA members were not contacted.

The authors prepared a standard Excel sheet for the NDAs to put in their own data. Each NDA used this Excel sheet to put in their own data and then send the Excel sheet to the authors electronically. Data obtained from the 6 NDAs were entered on a spread sheet and the frequency distribution of the responses was calculated. For data analyses, the chi-square test and Fisher exact test was used $(p<0.05)$. Demographic data were used to identify the potential differences between dental professionals in their attitudes and perceptions based on their age, gender, practice models and years of experience. All analyses were made with SPSS Statistics for Windows Version 20 (IBM Corp., Armonk, NY, USA). The percentage of responses to each questionnaire item was calculated in order to analyse cumulative data gathered from the six participating NDAs.

Pairwise comparisons of countries were performed

I implement clinical guidelines into my daily practice

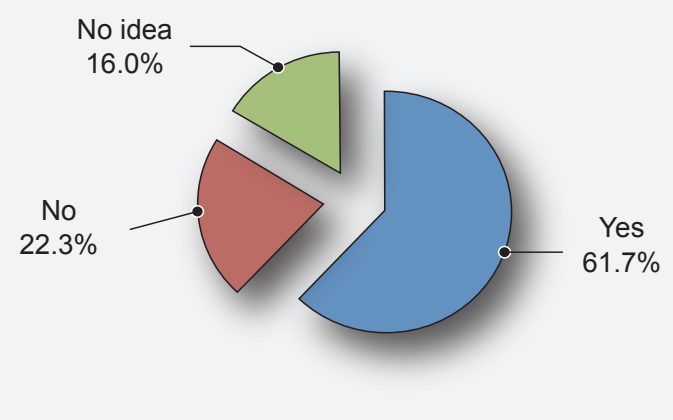

How often should clinical guidelines be updated?

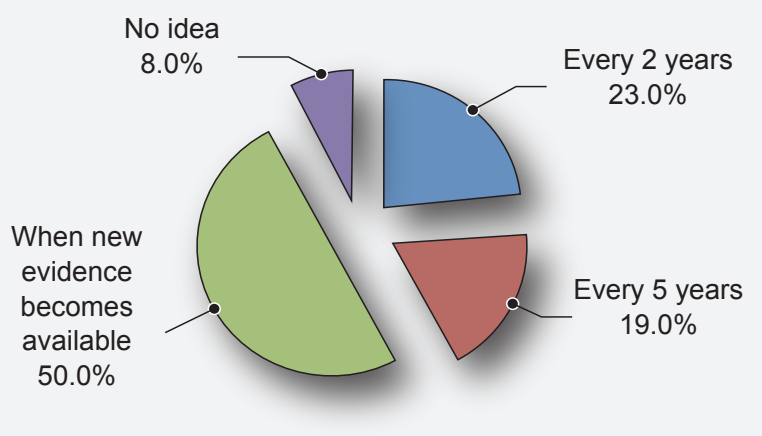

Figure 1 - Frequency of questionnaires completed by the participants of each of the six NDA's. Frequency of implementation of the clinical guidelines into daily practice. Groups benefiting from clinical guidelines and its implementation into daily practice. Frequency of the timeframe dentists think is required for updating the clinical guidelines. 
using the chi-square test $(p<0.05)$ in order to compare the differences among the participants from different countries regarding the extent of their awareness on and perceptions towards CDGs, perceived barriers for implementation of CDGs, opinions for effective use of CDGs in clinical practice and the process of development and review of CDGs. Factors with the potential to have an impact on the perceptions, attitudes and active use of CDGs by dental professionals (e.g. age, gender, years of practice and type of practice) were also analysed using the chi-square test ( $p$ $<0.05)$.

'Age ' of the respondents was categorized as '20 - 30', '31 - 40', ' $41-50$ ' and ' $\geq 51$ ' for comparison of age groups. Similarly, 'years of practice' was categorized as '0 - 10', ' 11 - 20', '21 - 30' and ' $\geq 31$ ', while 'type of practice' was evaluated under three categories, as follows: (i) General practice, or Specialist in dentistry; (ii) Private or public or Public and private; and (iii) Solo practice, or Solo practice in a medical clinic, or Group practice (in a dental clinic with other dentists), or Group practice (in a medical clinic with other dentists), or University faculty member (private university), or University faculty member (public university). In the third category, to obtain an adequate sample size for statistical analysis, the subcategories were combined into Solo practice, Group practice or University faculty member which enabled us to evaluate further the potential impact of mode of various practice models on the perceptions and attitudes towards CDG.

The data of this questionnaire study has been analyzed by using chi-square test due to the qualitative data. By chisquare test, pairwise comparisons of the the countries which are the independent variables are performed. Therefore, an increase in type 1 errors is not expected. Bonferroni correction which is used for multiple comparisons as Kruskal Wallis test has not been performed in this study where pairwise comparisons made.

\section{RESULTS}

A total of 910 responses were received from the participating members of GSA, RDA, PDA, SSO, ANDI, and TDA (Fig. 1).

\section{Demographic data}

Demographic characteristics of participants, expressed as number and frequency (percentage), are given in Table 1. Response rates to age, gender, years of practice and type of practice were different, and therefore the distribution of respondents according to these demographic variables was calculated on the basis of response rates. There were responders from all age categories, majority being over 31 years, while $16.3 \%$ were below 31 years. Most dentists were general dental practitioners $(65.5 \%)$ and in private practice $(75.5 \%)$, were either solo practitioners $(42.1 \%)$ or in group practice $(38.2 \%)$.

\section{Overall data from the participants $(n=910)$}

Table 2 presents the response to each question given by all participants without stratification according to the demographic variables. The majority $(68 \%)$ knew about CDGs, mainly from 'dental journals' $(24.8 \%)$ and 'continuing education courses' (23.1\%). CDGs were generally implemented into daily practice $(61.7 \%)$, either 'frequently' $(54.7 \%)$, or 'always' (27\%). The benefit of CDGs was highly acknowledged (81.8\%), in an equal manner for both dentists $(37.5 \%)$ and patients $(37.1 \%)$. The top reasons for limited implementation of CDGs into practice was 'lack of awareness' (29\%), followed by lack of time (13.9\%), difficulty in reaching CDGs $(11.1 \%)$ and limited number of guidelines in dentistry $(10.2 \%)$. More than half of the respondents suggested a role for NDAs, especially for 'creating a general awareness' (23.6\%), 'informing dentists about available (19.7\%) and updated (19.8\%) clinical guidelines'.

Table 1 - Demographic data $(n=910)$

\begin{tabular}{|c|c|c|}
\hline Characteristics & Number & Frequency (\%) \\
\hline \multicolumn{3}{|l|}{ Country } \\
\hline GDA & 92 & 10.1 \\
\hline RDA & 107 & 11.8 \\
\hline PDA & 262 & 28.8 \\
\hline SSO & 50 & 5.5 \\
\hline Italy - ANDI & 103 & 11.3 \\
\hline TDA & 296 & 32.5 \\
\hline \multicolumn{3}{|l|}{ Age } \\
\hline $20-30$ & 147 & 16.3 \\
\hline $31-40$ & 274 & 30.5 \\
\hline $41-50$ & 219 & 24.4 \\
\hline 51 - over & 258 & 28.7 \\
\hline \multicolumn{3}{|l|}{ Gender } \\
\hline Male & 420 & 46.6 \\
\hline Female & 481 & 53.4 \\
\hline \multicolumn{3}{|l|}{ Years of practice } \\
\hline $0-10$ & 324 & 35.8 \\
\hline $11-20$ & 234 & 25.9 \\
\hline $21-30$ & 220 & 24.3 \\
\hline 31 - over & 127 & 14 \\
\hline \multicolumn{3}{|l|}{ Type of practice } \\
\hline General practitioner & 586 & 65.8 \\
\hline Specialist & 305 & 34.2 \\
\hline \multicolumn{3}{|l|}{ Type of practice } \\
\hline Private & 689 & 75.5 \\
\hline Public & 122 & 13.5 \\
\hline Private and public & 90 & 10 \\
\hline \multicolumn{3}{|l|}{ Type of practice } \\
\hline Solo & 376 & 42.1 \\
\hline Group practice & 341 & 38.2 \\
\hline University & 174 & 19.5 \\
\hline Others & 2 & 0.2 \\
\hline
\end{tabular}


Most respondents were in favour of collaboration between dental faculties and NDAs for developing CDGs. 'Universities' (27\%) and 'NDAs' (22\%) were addressed for developing CGs. 'New evidence' was the essential measure for both the validity of CDGs, and for their update since almost half felt that available guidelines would be valid 'until new evidence becomes available' (47.4\%) and CDGs should be updated 'when new evidence becomes available'

Table 2 - Cumulative data for all participants (section 1 of 4 )

\begin{tabular}{|c|c|c|}
\hline Q1 - I know about clinical guidelines & $\mathbf{n}$ & $\%$ \\
\hline TOTAL & 910 & \\
\hline Yes & 612 & 68.0 \\
\hline No & 288 & 32.0 \\
\hline TOTAL & 1112 & \\
\hline I read them in dental journals & 278 & 24.8 \\
\hline $\begin{array}{l}\text { I read them on websites of specialization } \\
\text { organizations }\end{array}$ & 174 & 15.5 \\
\hline I use search engines to find them & 114 & 10.2 \\
\hline $\begin{array}{l}\text { My National Dental Organization sends me } \\
\text { information about them. }\end{array}$ & 176 & 15.7 \\
\hline $\begin{array}{l}\text { I learn about them from the continuing } \\
\text { education courses which I attend }\end{array}$ & 259 & 23.1 \\
\hline $\begin{array}{l}\text { I learned about them from my Undergraduate } \\
\text { dental education }\end{array}$ & 93 & 8.3 \\
\hline Other (please specify) & 18 & 1.6 \\
\hline TOTAL & 892 & \\
\hline Yes & 554 & 61.7 \\
\hline No & 197 & 22.3 \\
\hline No idea & 141 & 16.0 \\
\hline TOTAL & 578 & \\
\hline Always & 156 & 27.0 \\
\hline Frequently & 316 & 54.7 \\
\hline Sometimes & 76 & 13.1 \\
\hline Rare & 16 & 2.8 \\
\hline Very rare & 14 & 2.4 \\
\hline $\begin{array}{l}\text { Q5 - Do you believe that clinical guidelines } \\
\text { are generally beneficial? }\end{array}$ & $\mathbf{n}$ & $\%$ \\
\hline TOTAL & 866 & \\
\hline Yes & 708 & 81.8 \\
\hline No & 22 & 2.5 \\
\hline No idea & 136 & 15.7 \\
\hline $\begin{array}{l}\text { Q6 - If yes, I believe that clinical guidelines } \\
\text { can be beneficial because: }\end{array}$ & $\mathbf{n}$ & $\%$ \\
\hline TOTAL & 1147 & \\
\hline They can improve the accuracy of diagnosis & 202 & 17.6 \\
\hline They can improve the clinical treatment plan & 329 & 28.7 \\
\hline $\begin{array}{l}\text { They can decrease the time necessary for the } \\
\text { diagnostic process }\end{array}$ & 118 & 10.3 \\
\hline They can decrease treatment complications & 228 & 19.9 \\
\hline They can improve the outcome of treatment. & 253 & 22.1 \\
\hline Other (please specify) & 17 & 1.5 \\
\hline
\end{tabular}

(46.8\%) (Fig. 1).

\section{Data based on participants as members of different NDAs}

There were clear differences among the participating members of different NDAs regarding most of the questions included [Appendix 2 (Percentages of respondents considering each variable): https://www. actamedicaportuguesa.com/revista/index.php/amp/article/ view/8942/5307 and Appendix 3 (Statistical data regarding comparative analysis of the six NDA's): https://www.

Table 2 - Cumulative data for all participants (section 2 of 4)

\begin{tabular}{lcr}
$\begin{array}{l}\text { Q7 - Who benefits from clinical guidelines } \\
\text { and its implementation to dental } \\
\text { practice? }\end{array}$ & $\mathbf{n}$ & \% \\
\hline TOTAL & 1181 & \\
Dentists & 443 & 37.5 \\
Patients & 438 & 37.1 \\
Public & 111 & 9.4 \\
Dental profession & 173 & 14.6 \\
Other (please specify) & 16 & 1.4 \\
\hline Q8 - Do you believe that dentists implement & $\mathbf{n}$ & $\%$ \\
clinical guidelines into practice? & & \\
\hline TOTAL & $\mathbf{8 4 8}$ & \\
Yes & 303 & 35.7 \\
No & 232 & 27.4 \\
No idea & 313 & 36.9 \\
\hline
\end{tabular}

Q9 - If no, what are the barriers to implementation of clinical guidelines into practice? (more than one option)

TOTAL 922

Lack of time 122

13.4

Lack of awareness of clinical guidelines

Lack of practical ways to reach to clinical guidelines

Limited guidelines available in the dental field

Lack of evidence-based clinical guidelines for dental care

Clinical guidelines being perceived as restricting the 'clinical freedom of dentists'

Lack of consensus/agreement regarding certain aspects of the available guidelines

Limited knowledge regarding the reliability of the methods used for developing guidelines

Limited knowledge regarding the reliability of the guideline development group/body

Lack of confidence regarding competing interests of guideline development group

Limited knowledge regarding the regular update of the guidelines when new evidence becomes available

Lack of specific and unambiguous recommendations in the guideline

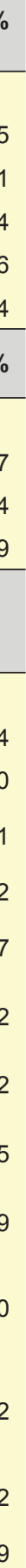


Table 2 - Cumulative data for all participants (section 3 of 4)

\begin{tabular}{|c|c|c|}
\hline $\begin{array}{l}\text { Q10 - Is there a role for the National Dental } \\
\text { Association regarding clinical guidelines? }\end{array}$ & $\mathbf{n}$ & $\%$ \\
\hline TOTAL & 852 & \\
\hline Yes & 484 & 56.8 \\
\hline No & 45 & 5.3 \\
\hline No idea & 323 & 37.9 \\
\hline TOTAL & 1167 & \\
\hline $\begin{array}{l}\text { Creating a general awareness on clinical } \\
\text { guidelines }\end{array}$ & 275 & 23.6 \\
\hline $\begin{array}{l}\text { Developing evidence-based clinical guide- } \\
\text { lines }\end{array}$ & 197 & 16.9 \\
\hline $\begin{array}{l}\text { Developing various evidence based-clinical } \\
\text { decision support systems including clinical } \\
\text { guidelines }\end{array}$ & 150 & 12.9 \\
\hline $\begin{array}{l}\text { Informing dentists about available clinical } \\
\text { guidelines }\end{array}$ & 230 & 19.7 \\
\hline $\begin{array}{l}\text { Informing dentists about updated clinical } \\
\text { guidelines }\end{array}$ & 231 & 19.8 \\
\hline $\begin{array}{l}\text { Attempts to overcome the barriers to imple- } \\
\text { mentation of clinical guidelines into practice }\end{array}$ & 78 & 6.6 \\
\hline Others (please specify) & 4 & 0.3 \\
\hline None & 2 & 0.2 \\
\hline TOTAL & 827 & \\
\hline Yes & 716 & 86.6 \\
\hline No & 31 & 3.7 \\
\hline No idea & 80 & 9.7 \\
\hline TOTAL & 1191 & \\
\hline Universities & 321 & 27 \\
\hline National Dental Associations & 262 & 22 \\
\hline Scientific communities & 223 & 18.7 \\
\hline Expert people & 132 & 11.1 \\
\hline Joint activity of various dental bodies & 218 & 18.3 \\
\hline Other (please specify) & 21 & 1.8 \\
\hline No idea & 14 & 1.2 \\
\hline
\end{tabular}

Q14 - Do you believe that dental faculties
and National Dental Associations can
$\begin{aligned} & \text { allaborate for disseminating clinical } \\ & \text { guidelines? }\end{aligned}$

\begin{tabular}{lcr}
$\begin{array}{l}\text { Q15 - Do you believe that clinical guideli- } \\
\text { nes should be valid for: }\end{array}$ & $\mathbf{n}$ & $\%$ \\
\hline TOTAL & 849 & \\
Up to 2 years & 224 & 26.4 \\
Up to 5 years & 154 & 18.1 \\
Until new evidence becomes available & 402 & 47.3 \\
No idea & 69 & 8.1
\end{tabular}

Table 2 - Cumulative data for all participants (section 4 of 4 )

\begin{tabular}{lcc}
$\begin{array}{l}\text { Q16 - How often should clinical guidelines } \\
\text { be updated? }\end{array}$ & $\mathbf{n}$ & $\%$ \\
\hline TOTAL & 842 & \\
Every 2 years & 197 & 23.4 \\
Every 5 years & 157 & 18.6 \\
When new evidence becomes available & 425 & 50.5 \\
No idea & 63 & 7.5 \\
\hline $\begin{array}{l}\text { Q17 - Do you know any clinical guidelines } \\
\text { that should be introduced (please provide } \\
\text { the title and the web address) }\end{array}$ & $\mathbf{n}$ & \\
\hline
\end{tabular}

${ }^{*}$ Multiple choice questions

actamedicaportuguesa.com/revista/index.php/amp/article/ view/8942/5308]. For example, although the participants who were members of the RDA, ANDI and SSO were generally aware of CDGs, there were differences in the extent of knowledge/awareness on CDGs among the participants from the six NDAs (Fig. 2). In general, participants from the most of NDAs reported a high level of implementation of CDGs into practice (ANDI (90.3\%), SSO (86\%), PDA $(79.8 \%)$, RDA $(75.7 \%)$. However, PDA and ANDI were significantly different from others $(p<0.05)$. Participants from all of the six NDAs, dentists implemented CDGs into their dental practice either 'frequently' (68.8\% - 40\%) or 'always' (42\% - 22.6\%). When benefits of CDGs were concerned, there the differences between participants from PDA and RDA; SSO, and ANDI $(p<0.05)$. Data regarding potential barriers are presented in Appendix 2. 'Lack of awareness' was the most frequently perceived barrier by all participants of NDAs, except TDA. Most members of NDAs suggested a role for NDAs (Fig. 2) including 'creating awareness' [GSA (29.7\%), RDA (26\%), Italy-ANDI (27.4\%)] and a collaboration between dental faculties and NDAs, in almost all countries, especially for dissemination of CDGs.

Data regarding the potential impact of demographic variables on perceptions and attitudes towards clinical dental guidelines (CDG):

Appendix 4 [Appendix 4 (Data regarding the impact of age, gender, years of practice, and type of practice on the responses): https://www.actamedicaportuguesa.com/ revista/index.php/amp/article/view/8942/5309] shows the impact of gender, age, type of practice and years of practice on the responses of dentists. It can easily be seen that all these variables had a certain effect on different items. For example, age and years in practice did not have a significant effect on dentists' knowledge about CDGs'. However, the knowledge was higher for males than females, 'specialist' rather than 'general practitioner', 'dentists working in public' or 'public and private' rather than only 'private practitioners' and 'faculty members' rather than 'dentists in group practice' and 'solo practicing' dentists. The primary sources of information for CDGs for older dentists or dentists with more practice years were 'dental 
‘I know about clinical guidelines‘

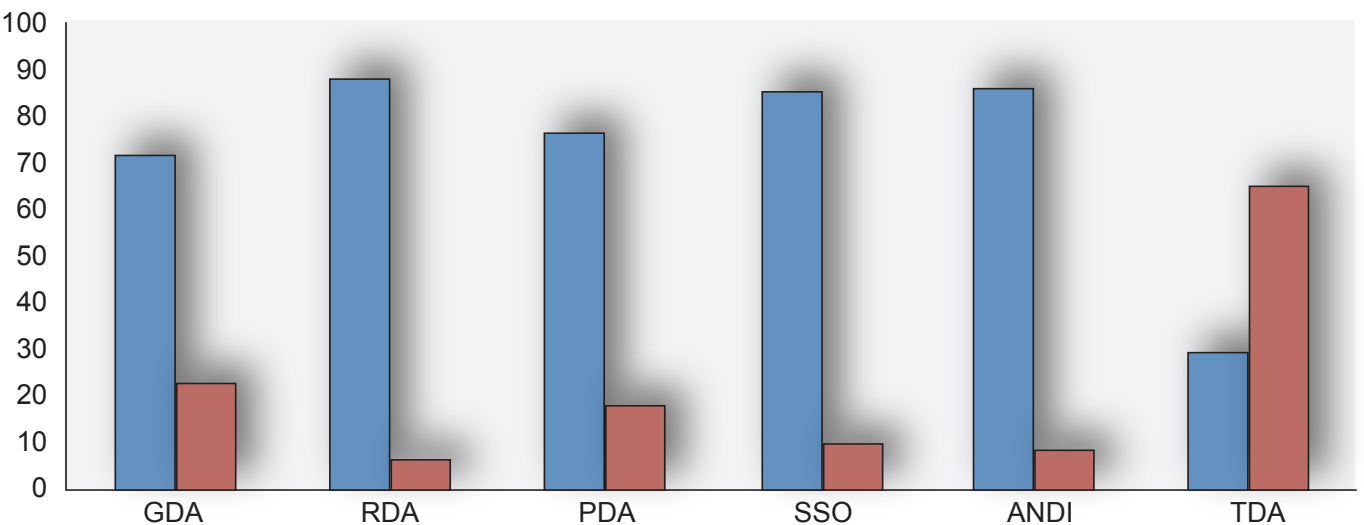

\section{Do you believe that dentists implement clinical guidelines into practice?}

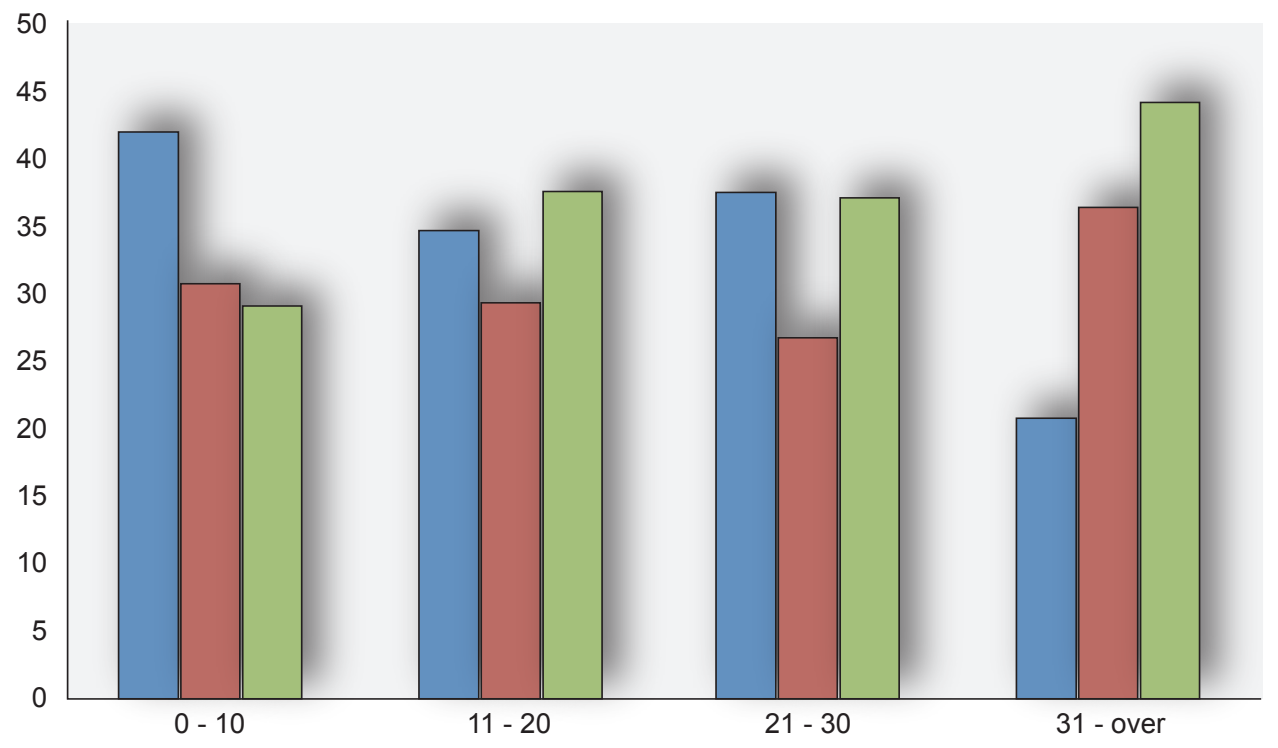

Is there a role for the National Dental Association regarding clinical guidelines?

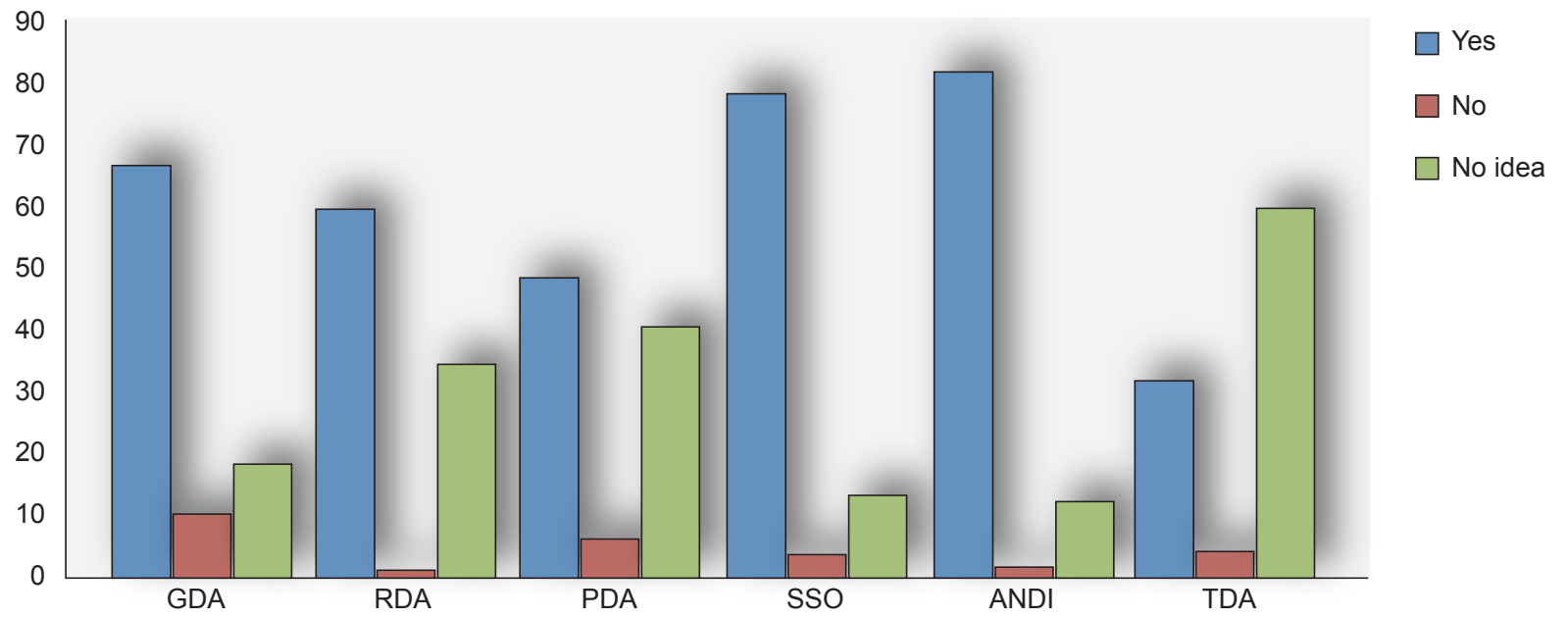

Figure 2 - Awareness of the existence of clinical guidelines by country. Participants' opinion concerning the role of the national dental association regarding clinical guidelines by country. Estimated frequencies of the implementation of clinical guidelines into daily practice according to years of practice. 
journals' or 'information sent by NDAs', while for younger dentists or dentists with less years of practice 'web sites', 'continuing education courses' and 'undergraduate education' were the primary sources of information. 'Type' of practice' was likely to be the more prominent factor in affecting the attitudes and perceptions of dentists. As an example, age, gender, and years in practice did not have a significant effect on 'dentists' implementation of CG into daily practice'. However, type of practice had an impact ( $p$ $<0.05)$, since higher implementation for 'specialists' rather than 'general dental practitioners' $(p=0.001)$, for dentists working in 'public' and 'public/private' rather than dentists in 'private practice' $(p=0.019)$ was observed. In a similar manner, type of practice had an effect on the frequency of implementation of CDGs into daily practice and the benefits of CDGs $(p<0.05)$. 'Frequent' implementation was reported more for specialists than general dental practitioners $(p=$ $0.001)$ while 'always' was reported more for specialists ( $p$ $=0.001$ ). The highest frequency for 'always' was observed for dentists working in public practice (40.5\%) and for 'frequently' dentists working in private practice $61.4 \%$ ( $p=$ 0.038 ). Dentists working in 'public practice' believed in the benefits of CDGs (89.3\%), followed by 'private and public practice' $(83.3 \%)$, while the least was for 'private' mode of practice $(74.9 \%)$. Participants mostly believed that CDGs could improve the clinical treatment plan (50.6\%) and improvement of accuracy of diagnosis (39.4\%) and this increased with the age and years of practice $(p<0.05)$, and was prominent for specialists $(47.9 \%, 28.2 \%)$ rather than general dental practitioners $(29.9 \%, 18.9 \%)$. Data for implementation of CDGs into daily practice is presented in (Fig. 2). Significantly higher percentage of dentists working in public indicated 'Lack of time' as a barrier, while 'Limited guidelines available in the dental field' and 'Clinical guidelines being perceived as restricting the clinical freedom of dentists' was indicated mostly by specialist, dentists working in public practice, and academics $(p<0.05)$. Regardless of demographic variables, more than $75 \%$ of dentists believed that 'dental faculties and NDAs could collaborate for developing CG' and more than $80 \%$ believed that they could collaborate for effective dissemination of CDGs. However, there were differences based on age, gender and type of practice, regarding the developing and disseminating body (E.g. universities, NDAs, 'joint activity of various dental bodies') and the duration of the validity of CDGs (in years) $(p<0.05)$. Although 'when new evidence becomes available' was the main answer with no impact of age and years in practice $(p>0.05)$, there was a difference between dentists working in private practice and university members compared to other modes of practice $(p<0.05)$ regarding the appropriate time for update.

\section{DISCUSSION}

The dental professionals participating in this survey comprise a small sample. Thus, it needs to be kept in mind that is not possible to generalize the results to all the dental professionals in these countries. However, since the study reflects the perceptions and attitudes of a total of 910 dentists as members of different NDAs and different backgrounds, who all were interested in this topic and were willing to provide feedback, it is still considered as a study which conveys a better understanding of the current status of CDGs and their implementation into practice. One of the important gains can be the confirmation of the presence of a general positive attitude of dental professionals towards CDGs and acknowledgement of their benefits, as this can encourage the dental profession to expand the development of reliable and valid CDGs, in-line with the needs and demands of dental professionals. On the other hand, the 'broad picture' of the 'perceived barriers' regarding the implementation of CDGs into practice and the opinions/ suggestions of dental professionals for a more effective use of CDGs may assist the dental educators and the organized dentistry to find more innovative ways of disseminating and promoting CDGs.

The 'multidimensional' benefits of CDGs were widely acknowledged $(81.8 \%)$ in the present study, since the benefit of CDGs for improvement of the clinical treatment plan $(28.6 \%)$, outcome of the treatment $(22.8 \%)$ and the accurate diagnosis $(17.4 \%)$ and, decreasing the treatment complications (19.9\%) and the time necessary for diagnosis $(10 \%)$ were all underlined. Furthermore, besides dentists $(37.5 \%)$, patients $(37.1 \%)$ were also identified as beneficiaries from CDGs. This finding supports the earlier general positive attitude towards clinical guidelines and highlights their benefits for both dentists and patients. $6,8,11,18,23$ In many countries CDGs do not seem to be systematically disseminated and implemented nationwide. ${ }^{8}$ However, this is not restricted to dentistry and ineffective dissemination and limited implementation has been reported for other health professions including medicine ${ }^{20}$ and nursing. ${ }^{7}$ The limited implementation of CDGs was again observed in the present survey. Although these results cannot be claimed to reflect all dentists in a given country, since it was observed as a common situation among the members of the six NDAs, they can still confirm the earlier evidence that availability does not automatically lead to effective use of CGs. ${ }^{7,8,20}$

Certain barriers exist regarding the implementation of CGs into practice (e.g. lack of interest, lack of involvement, lack of information, lack of time)., ${ }^{7,19}$ Very similar barriers were highlighted by the survey participants, with the most important barriers being 'lack of awareness' (29\%), 'lack of time' (13.4\%), 'lack of practical ways to reach CDGs' $(11.1 \%)$, and limited availability of CDGs in the dental field $(10.2 \%)$. It is also worth mentioning that the fear of CDGs restricting clinical freedom and autonomy of dentists ${ }^{8}$ was also expressed in the present study (5.2\%).

Recently, efficacy (efficacy of guidelines in changing health professionals and patients behaviour) is a concern and an increased attention is paid to the methodology of guideline development. ${ }^{24}$ Health professional's attitude towards clinical guidelines would be an important parameter and it should be noted that the attitude of health care professionals may change over time according to the 
validity of the guideline. ${ }^{20}$

Changes in the available interventions, in the evidence on the benefits and harms of existing interventions, in the outcomes that are considered important, in the values placed on outcomes, in the evidence that current practice is optimal are situations that indicate that a guideline should be revised or updated. ${ }^{25}$ However, there is no consensus regarding the time interval and methodology to update a guideline. In the literature it was reported that about half of the guidelines became outdated in 5.8 years and no more than $90 \%$ of the guidelines were still valid 3.6 years after publication. As such, it was suggested that guidelines should be assessed after 3 years. ${ }^{20}$ In the present survey responders also frequently chose 'every two years' and 'every five years' as the frequency of CDGs reassessment. A group of people, exerting a specific role in the guideline development process, is required.,12 It is suggested that guidelines developed by the clinicians to whom they are intended were more successful in changing clinical behaviour ${ }^{24}$ and with no conflict of interest. ${ }^{20}$ Moreover, experts from different countries are necessary for development of international guidelines to adapt them to meet local needs and socio-economic and health care standards and resources. ${ }^{20}$ In the present study, although universities were suggested as the primary group, other groups were also suggested to be involved in developing CDGs (e.g. NDAs, scientific committees, joint activities of various dental bodies, expert people).

Translating scientific knowledge into practice is challenging and developing guidelines and disseminating them is an important part of this procedure. While dissemination alone is not an adequate way of changing practice, it is a prerequisite for guideline implementation. ${ }^{7}$ Publication of guidelines in professional journals and mailing them to targeted individuals are passive methods of dissemination and rarely leads to change in clinical approach. ${ }^{26}$ In the present survey, the most common dissemination tools were dental journals and continuing education courses. Getting information from NDAs and reading them on websites of special organizations were the other common sources of information on CDGs. A collaboration of dental faculties and NDAs for effective dissemination of CDGs was also suggested (88.2\%).

It has been shown that demographic variables have impact on health professional's perceptions and attitudes and this has been shown for health professionals of different backgrounds (e.g. physicians, dentists, nurses). ${ }^{27-32}$ For example, the impact of age, gender, years of practice and type of practice on the perceptions and attitudes of dental professionals regarding EBD was documented. ${ }^{27}$ The present study is in line with these previous studies ${ }^{27,28}$ as a clear impact of age, gender, years of practice and 'type' of practice' on dentists perceptions and attitudes towards CDGs and their implementation into dental practice was concerned. Age and gender had impact even though type of practice seemed to have the most prominent impact. Knowledge about CDGs, implementing CDGs into daily practice, believing the benefits of CDGs were all specifically affected by 'type of practice' was determinant. Thus, besides other demographic variables, the significant importance of working conditions of dental professionals' perceptions and attitudes may be suggested.

In the literature, there are studies observing differences in perceptions and attitudes of health professionals from different countries, related with different social, economical and cultural circumstances. ${ }^{33-37}$ The clear differences among countries regarding provision of oral health care services, oral health care needs and demands, dental education, composition of dental team and available oral health workforce, and basic oral health coverage and insurance systems are well documented. ${ }^{38-40}$ In a similar manner, differences in perceptions and attitudes towards various professional matters and issues of dental professionals' from different countries have also been documented..$^{27,33-36,41}$ Despite the limited number of participants and within the limitations of the study design, the differences in the perceptions and attitudes of dentists towards CDGs observed in the present study are shaped by local circumstances. This may be of particular importance for attempts aiming at overcoming the barriers for effective implementation of CDGs into daily practice as each specific barrier may require a different approach again based on the local circumstances.

\section{CONCLUSION}

Although the influence of individual characteristics, different professional backgrounds, and geographical/ cultural differences was evident, it is quite clear that dentists were generally positive towards CDGs. However, at the same time, dentists had some very clear and common concerns about CDGs' reliability, availability, updating, and applicability and they expressed certain barriers making their effective implementation to everyday practice difficult. In order to achieve the major goals of CDGs, it will be necessary to increase their efficacy as well as patient safety and quality of care through effective implementation of CDGs into daily practice, and to take in consideration the opinions and attitudes of dental professionals. At this point, all structures of organized dentistry (specialist organizations, dental faculties, dental associations, etc.) are likely to have important roles.

\section{ACKNOWLEDGEMENTS}

The authors wish to thank the members of the World Dental Federation (FDI) - European Regional Organization (ERO) Working Group 'Relation Between Dental Practitioner and Universities' for their kind support. The authors also are grateful to the national dental associations which participated in the survey. The present study did not receive any financial support.

\section{PROTECTION OF HUMANS AND ANIMALS}

The authors declare that the procedures were followed according to the regulations established by the Clinical 
Research and Ethics Committee and to the Helsinki Declaration of the World Medical Association.

\section{DATA CONFIDENTIALITY}

The authors declare having followed the protocols in use at their working center regarding patients' data publication.

\section{REFERENCES}

1. Kredo T, Bernhardsson S, Machingaidze S, Young T, Louw Q, Ochodo $\mathrm{E}$, et al. Guide to clinical practice guidelines: the current state of play. Int J Qual Health Care. 2016;28:122-8.

2. Field MJ. Institute of Medicine. Washington: The National Academies Press; 1990.

3. Clinical Practice Guidelines We Can Trust. Washington: The National Academies Press; 2011.

4. Nothacker M, Stokes T, Shaw B, Lindsay P, Sipilä R, Follmann M, et al. Reporting standards for guideline-based performance measures. Implement Sci. 2016;11:6.

5. Woolf SH, Grol R, Hutchinson A, Eccles M, Grimshaw J. Clinical guidelines: potential benefits, limitations, and harms of clinical guidelines. BMJ. 1999;318:527-30.

6. Faggion CM Jr. The development of evidence-based guidelines in dentistry. J Dent Educ. 2013;77:124-36.

7. Miller M, Kearney N. Guidelines for clinical practice: development, dissemination and implementation. Int J Nurs Stud. 2004;41:813-21.

8. van der Sanden WJ, Mettes DG, Plasschaert AJ, van't Hof MA, Grol $\mathrm{RP}$, Verdonschot EH. Clinical practice guidelines in dentistry: opinions of dental practitioners on their contribution to the quality of dental care. Qual Saf Health Care. 2003;12:107-11.

9. Eccles M, Mason J. How to develop cost-conscious guidelines. Health Technol Assess. 2001;5:1-69.

10. Cluzeau F, Littlejohns P, Grimshaw JM. Appraising clinical guidelines: towards a "which" guide for purchasers. Qual Health Care. 1994;3:121-

11. Seale NS. AAPD Clinical Practice Guidelines-why they are more important than ever. Pediatr Dent. 2013;35:404-5.

12. Lang NP, Kinane DF, Lindhe J, Sanz M, Tonetti MS. Sixth European Workshop on Periodontology of the European Academy of Periodontology at the Charterhouse at Ittingen, Thurgau, Switzerland. J Clin Periodontol. 2008;35:1-2.

13. Sarkis-Onofre R, Cenci MS, Demarco FF, Lynch CD, Fleming PS, Pereira-Cenci $\mathrm{T}$, et al. Use of guidelines to improve the quality and transparency of reporting oral health research. J Dent. 2015;43:397404.

14. Uppal E. Clinical guidelines. Pract Midwife. 2016;19:13-6.

15. Esposito M. Editorial: on clinical guidelines. Eur J Oral Implantol. 2014;7:3.

16. Carrilho E, Dianiskova S, Guncu GN, Karakoca Nemli S, Melo P, Yamalik N. Practical implementation of evidence-based dentistry into daily dental practice through a short time dependent searching method. J Evid Based Dent Pract. 2016;16:7-18.

17. Fletcher SW, Fletcher RH. Development of clinical guidelines. Lancet. 1998;352:1876.

18. Long CM, Quinonez RB, Rozier RG, Kranz AM, Lee JY. Barriers to pediatricians' adherence to American Academy of Pediatrics oral health referral guidelines: North Carolina general dentists' opinions. Pediat Dent. 2014;36:309-15.

19. Clarkson JE. Getting research into clinical practice - barriers and solutions. Caries Res. 2004;38:321-4.

20. Van Hoecke $H$, Van Cauwenberge P. Critical look at the clinical practice guidelines for allergic rhinitis. Respir Med. 2007;101:706-14.

21. Polk DE, Nolan BA, Shah NH, Weyant RJ. Policies and procedures that facilitate implementation of evidence-based clinical guidelines in U.S. dental schools. J Dent Educ. 2016;80:23-9.

22. World Medical Association. Declaration of Helsinki: Ethical principles for medical research involving human subjects. J Am Coll Dent. 2014;81:148.

23. Bonetti D, Johnston M, Pitts NB, Deery C, Ricketts I, Bahrami M, et al. Can psychological models bridge the gap between clinical guidelines and clinicians' behaviour? A randomised controlled trial of an intervention

\section{CONFLICTS OF INTEREST}

The authors declare no conflict of interest.

\section{FUNDING SOURCES}

This research received no specific grant from any funding agency in the public, commercial, or not-for-profit sectors.

to influence dentists' intention to implement evidence-based practice. $\mathrm{Br}$ Dent J. 2003;195:403-7.

24. Carrasco-Labra A, Brignardello-Petersen R, Glick M, Guyatt GH, Neumann I, Azarpazhooh A. A practical approach to evidence-based dentistry: VII: How to use patient management recommendations from clinical practice guidelines. J Am Dent Assoc. 2015;146:327-36.

25. Shekelle P, Eccles MP, Grimshaw JM, Woolf SH. When should clinical guidelines be updated? BMJ. 2001;323:155-7.

26. Grimshaw JM, Russell IT. Achieving health gain through clinical guidelines II: Ensuring guidelines change medical practice. Qual Health Care. 1994;3:45-52.

27. Yamalik N, Nemli SK, Carrilho E, Dianiskova S, Melo P, Lella A, et al. Implementation of evidence-based dentistry into practice: analysis of awareness, perceptions and attitudes of dentists in the World Dental Federation-European Regional Organization zone. Int Dent J. 2015;65:127-45.

28. Chapman R, Zappia T, Shields L. An essay about health professionals attitudes to lesbian, gay, bisexual and transgender parents seeking healthcare for their children. Scand J Caring Sci. 2012;26:333-9.

29. Meneses SR, Goode AP, Nelson AE, Lin J, Jordan JM, Allen KD, et al. Clinical algorithms to aid osteoarthritis guideline dissemination. Osteoarthritis Cartilage. 2016;24:1487-99.

30. Rouse B, Cipriani A, Shi Q, Coleman AL, Dickersin K, Li T. Network meta-analysis for clinical practice guidelines: a case study on first-line medical therapies for primary open-angle glaucoma. Ann Intern Med. 2016;164:674-82.

31. Jokhan S, Whitworth MK, Jones F, Saunders A, Heazell AE. Evaluation of the quality of guidelines for the management of reduced fetal movements in UK maternity units. BMC Pregnancy Childbirth. 2015;15:54.

32. Hoffman JM, Dunnenberger HM, Kevin Hicks J, Caudle KE, Whirl Carrillo $M$, Freimuth RR, et al. Developing knowledge resources to support precision medicine: principles from the Clinical Pharmacogenetics Implementation Consortium (CPIC). J Am Med Inform Assoc. 2016;23:796-801.

33. Schnitzbauer AA, Proneth A, Pengel L, Ansorg J, Anthuber M, Bechstein WO, et al. Evidence-based medicine in daily surgical decision making: a survey-based comparison between the UK and Germany. Eur Surg Res. 2015;54:14-23.

34. Mehl C, Wolfart S, Vollrath O, Wenz HJ, Kern M. Perception of dental esthetics in different cultures. Int J Prosthodont. 2014;27:523-9.

35. Mehl C, Harder S, Lin J, Vollrath O, Kern M. Perception of dental esthetics: influence of restoration type, symmetry, and color in four different countries. Int J Prosthodont. 2015;28:60-4

36. Papastavrou E, Efstathiou G, Tsangari $H$, Suhonen R, Leino-Kilpi $H$, Patiraki E, et al. A cross-cultural study of the concept of caring through behaviours: patients' and nurses' perspectives in six different EU countries. J Adv Nurs. 2012;68:1026-37.

37. Karibe H, Suzuki A, Sekimoto T, Srithavaj ML, lamaroon A, Warita S, et al. Cross-cultural comparison of the attitudes of dental students in three countries. J Dent Educ. 2007;71:1457-66.

38. Yamalik N, Ensaldo-Carrasco E, Cavalle E, Kell K. Oral health workforce planning part 2: figures, determinants and trends in a sample of World Dental Federation member countries. Int Dent J. 2014;64:117-26.

39. Yamalik N, Ensaldo-Carrasco E, Bourgeois D. Oral health workforce planning. Part 1: Data available in a sample of FDI member countries. Int Dent J. 2013;63:298-305

40. The Challenge of Oral Disease - A call for global action. The Oral Health Atlas. No. FDI Washington: World Dental Federation; 2015

41. Yamalik N, Van Dijk W. Analysis of the attitudes and needs/demands of dental practitioners in the field of patient safety and risk management. Int Dent J. 2013:63:291-7. 